\title{
MAPPING THE Field of ENVIRONMENTAL Justice: Redistribution, ReCognition and Representation in ENGO PRess
}

ADVOCACY

HOWARD RAMOS

Abstract. The environment is increasingly seen as a meta-injustice or master frame of the politics of the new century. If this is indeed the case, environmental concerns should transcend national and organizational boundaries and should have a discursive claims-making space of their own. Research on environmental advocacy, however, shows that many claims for environmental justice are rooted in specific locales and advocacy is often mediated through, and at times overshadowed by, other dimensions of power. Using Nancy Fraser's conception of dimensions of justice, and a Bourdieusian inspired field approach, this paper maps Greenpeace and Sierra Club's press advocacy between 2006 and 2010. In doing so, the paper identifies environmental advocacy spaces and argues that non-parametric approaches to analysing ENGO media advocacy are needed to explain the complexity of multi-scaled political contexts.

Keywords: Environment, Field Theory, Injustice, Bourdieu, Greenpeace, Sierra Club, Social Movement

Résumé. De plus en plus, l'environnement est perçu comme un cas de métainjustice et comme le cadre principal des politiques du nouveau siècle. Si cette perception est juste, les questions environnementales transcendent les limites nationales ou organisationnelles. À ce titre, l'environnement a le droit d'avoir son propre discours pour réclamer son propre espace. Toutefois, les recherches sur la défense de l'environnement montrent que nombre de plaidoyers prennent leur source dans des préoccupations locales. De plus, nous disent les études, il arrive que ces mêmes plaidoyers passent pas d'autres dimensions du pouvoir et sont mêmes oblitérés par elles. En nous appuyant sur la conception des dimensions de la justice de Nancy Fraser et en nous inspirant de la théorie des champs de Bourdieu, nous faisons ici la cartographie des communiqués de presse de Greenpeace et du Sierra Club publiés entre 2006 et 2010. C'est ainsi que notre article identifie des lieux de défense de l'environnement et met en avant qu'il faut des approches non paramétriques des interventions des ONGE (organismes 
non gouvernementaux à caractère environnemental) pour expliquer la complexité des contextes politiques multi niveaux.

Mots clés: 1 'environment, théorie des champs, l'injustice, Bourdieu, Greenpeace, Sierra Club, movement social

\section{INTRODUCTION}

uring the course of the last decade environmental issues have gained prominence in most industrialized societies. ${ }^{1}$ Much of the attention has been the result of advocacy by Environmental Non-Governmental Organizations (ENGOs) that use naming and shaming of companies and governments in mainstream media to promote more sustainable lifestyles, to raise awareness of environmental issues, and to protect endangered animals and fragile ecosystems.

The importance of the environment has led many to argue its politics are a central concern for the $21^{\text {st }}$ century. GlobeScan polling of 34 countries, for instance, shows that the proportion of people feeling that climate change is a very serious concern has increased dramatically over the 2000s (Leiserowitz 2007: 5) and that in each county the majority of citizens felt that climate change or global warming is a problem. Keck and Sikkink (1998: 10), moreover, show that global environmental advocacy networks have grown faster than other transnational movements, and Sklair (2002: 275) contends that the environmental movement may currently pose the biggest political threat to global capitalism. This has led some, such as Taylor (2000: 566), to claim that the environmental justice paradigm is a master frame and that it is highly successful because of its ability to link into other social justice issues. This is echoed by Fraser (2010: 25) who argues that environment harms are meta-level injustices that intersect with, and transcends, other dimensions of justice and national contexts.

Other research on environmental activism and media claims-making, however, shows that local media have distinct preferences for covering environmental claims tied to economic growth and wellbeing (Andrews and Caren 2010), suggesting that the environment is not a meta-level

1. I would like to thank Paul F. Armstrong and Andreas Hoffbauer for their work as research assistants on this project. Yoko Yoshida and Joshua Brisson offered valuable advice and feedback on the correspondence analysis. I am also indebted to the anonymous reviewers and the editors of this special issue, Petra Hroch and Mark C.J. Stoddart, for their suggestions on tightening the focus of the paper. The research was funded by the Social Science and Humanities Research Council of Canada. 
injustice but rather one mediated through economic and other political concerns. This is also seen when environmental harms are treated as actants that drive social and political actors to engage them. Much media and ENGO engagement of the environment occurs irrespective of the properties of actual environmental problems (Hoffbauer and Ramos 2014). At the same time, many ENGOs "go local" rather than global in their activism (Stoddart and Ramos 2013). This finding is echoed by research on social movements that observes that local context shapes diffusion of tactics and issues. Research also shows that most movements focus on municipal and provincial politics rather than reaching outward to the national and international contexts.

As a result, environmental harms are both a meta-level injustice and at the same time mediated through other justice claims and the politics of specific discursive spaces. Environmental issues are contested in multi-scaled political contexts, which are ill-suited to geographically and organizationally bound analyses. This paper explores this problem by mapping the field of ENGO media engagement of environmental issues. It does so by looking at the deployment of four types of justice claims used in environmental media advocacy by Greenpeace and the Sierra Club to identify environmental discursive space and to understand how a field approach and non-parametric methods can offer useful insight for understanding social movement media claims-making and the mediation of environmental justice. The paper begins with a literature review and a presentation of methods, continues with an analysis, and ends with some concluding reflections and possibilities for further analyses.

\section{Literature ReView}

Research on transnational activism has gained increasing attention over the last couple of decades with the rising prominence of social justice advocacy across borders. Much of the literature on this trend examines the rise of transnational networks (Smith 1998; Keck and Sikkink 1998), how international political institutions offer new venues for political action (della Porta 2005; Montpetit 2003), and the emergence of new frames of injustice that respond to global issues or engage transnational institutions (Tarrow 2005; della Porta et al. 2006; Wood 2012). Some of the most prominent transnational justice frames include human rights, indigenous rights, women's rights, and the environment (Keck and Sikkink 1998; Smith 1998; Bob 2005; Fraser 2010). This has led some to claim that these are master frames of the contemporary era (Taylor 2000) 
and others to claim that they are meta-level injustices that transcend particular contexts and encompass competing claims for justice.

In a series of works engaging (in)justice, Nancy Fraser (2005; 2008; 2010) identifies three dimensions of justice claims: redistribution, recognition, and representation. These roughly equate to justice claims over economic and material resources (redistribution), social and cultural status (recognition), institutional or political power (representation). Fraser argues that redistribution and recognition are first-order injustices that can be resolved within nation-states and existing polities. Like Keck and Sikkink (1998) and world society theorists (e.g. Meyer, Boli, Thomas and Ramirez 1997), Fraser argues that as groups seeking justice at the nation-state level face blockage and a lack of political representation, they increasingly appeal to transnational authorities and frames of justice. This leads her to argue that some injustices occur at a meta-level, appealing to people in multiple (if not all) contexts, which necessitates an investigation of how such injustices are framed and adjudicated. In effect, the legitimacy of state-based frames come into question as groups appeal to authority outside them and thus the moral criteria used to assess justice is simultaneously questioned. Fraser in turn argues that the contemporary period is one of abnormal politics and justice, wherein citizenship and representation in states as well as the authority of existing polities to adjudicate justice is questioned.

The properties of environmental problems certainly fit Fraser's notion of meta-level injustice. Climate change, depletion of natural resources, and the endangerment of ecosystems and biodiversity are all problems that transcend a given state. One can also readily cite countless examples of environmentalists launching international campaigns to save the environment. Think, for instance, of activism against bitumen extraction, the Keystone XL and Gateway pipelines, or hydraulic fracturing near Elsipogtog as just a few examples. In each case activists faced barriers in their local and national contexts and in turn tapped into broader transnational networks. In each case activists also questioned econocentric justifications used by states to promote environmental harms and instead espoused ecological and Indigenous claims to justice in opposition to these justifications. And last, in each case environmental advocates gained widespread media attention.

While it is clear that international institutions and transnational relations have opened space for advocacy across boarders and on potentially meta-level injustices, national and local governments are still important focal points of movement activism (Smith 2007). In fact, many movements "go local" rather than transnational in their politics (Stoddart and Ramos 2013). Many environmental problems are immediate and can be 
resolved without needing to appeal to international audiences. Mundane "Not In My Back Yard (NIMBY) activism likely accounts for far more environmental politics than environmentalism at the international level. The importance of the local is echoed by research on social movements more generally, leading McAdam et al. (2005) to conclude that most social movement theory distorts understandings of everyday activism because of its focus on national and international scales of politics. Relatedly, activists fear that local issues will be lost in bigger transnational movements (Wood 2012). If this is the case, injustices may be meta-level in their effect on people across polities, but they are not meta-level in their politics nor in the claims-making used to contest them.

Andrews and Caren (2010), for instance, showed that local movements that work within dominant political spaces and that package their environmental-claims according to the interests of local media, which have distinct preferences for covering environmental claims tied to economic growth and human wellbeing, are more successful in garnering attention than those that adopt un-mediated environmentalism. The mediation of the environment with other dimensions of justice was also observed by Hoffbauer and Ramos (2014) who saw that in the face of the BP oil spill in the Gulf of Mexico much media coverage and political engagement of the disaster was tied to economic and social injustices rather than the direct environmental harms caused by the spill. Such mediation is likewise evidenced in other research on environmental problems, which shows that more complex harms with global consequences, such as climate change, garner far less media attention and public support because they are less immediate, rely on expert interpretation, and have conflicting findings (Futrell 2003; Leggett 2001). This observation is partially linked to why Downs (1972) observed that dramatic and exciting environmental problems gain more attention than those that may cause more harm but are more mundane and quotidian.

This leaves an interesting puzzle. On the one hand environmental issues, their politics, and their advocacy are increasingly recognized as global and all-encompassing. This global and complex dimension of environmental issues has led Fraser, among others, to claim that they exist at a meta-level and transcend other dimensions of justice, such as economic or cultural forms, that are often resolved in national and other more local polities. On the other hand, others have shown that environmental harms might affect all people, but their politics, their advocacy, and the media and public attention they receive are mediated through other dimensions of justice and specific political contexts.

The contestation of environmental harms, as the literature reviewed thus far suggests, operates in multi-scaled political contexts -the global, 
national, regional, and local scales. Environmental advocacy thus requires an investigation that allows for multi-dimensionality. Such a mode of investigation has been advocated by Nick Crossley (2002; 2003), who recognizes that much of the dominant American literature on social movements suffers from a focus on narrowly defined political structures, which miss the complexity of the range of social life and relationships among dimensions of power. He also recognizes that political structures operate alongside and overlap with other social structures (2002: 14). For example, claims for economic justice will at times overlap social and environmental justice. It is thus worthwhile to consider how one can analyse multi-scaled and multi-dimensional advocacy. Crossley argues that Pierre Bourdieu's basic theoretical framework, with some modification, provides a pathway for such multiply-oriented analysis (2003: 45).

Crossley contends that like many social movement researchers, Bourdieu overlooked everyday contention in social movement politics by focusing on moments of crisis. He thus argues that Bourdieu's theory is focused on understanding dynamics of maintaining existing social order and change is only understood in extreme circumstances. As a result, Crossley argues that Bourdieu's theory needs some modification to see how social movement politics and change work in more subtle as well as extreme forms. Others recognize the usefulness of Bourdieu's notion of field as a tool for understanding complex relations and to understand nested social structures (Martin 2003; Emirbayer and Johnson 2008). If we accept that the environment is an issue that is both transnational and local and that it may be a master frame of its own or an issue mediated through other forms of justice, a field approach that analyzes multiple dimensions and different relationships seems promising.

To elaborate, the notion of a social field is developed in a number of Bourdieu's works (e.g. Bourdieu 1993; 1998; 2010 and with Wacquant 1992), however, it is most commonly recognized in English language and North American social science through his book, Distinction: A Social Critique of the Judgement of Taste (Lizardo 2012). Sallaz and Zavisca (2007) and Thomson (2008) recognize that fields can be understood in at least three ways: a space of social positions, a series of relational forces, and a space of contestations. Yet another understanding is offered by Steinmetz (2008: 591), who argues that "a field is a structured space of objective positions that operate as a universes of possible stances, a 'space' of possibilities or options given to participants in the field at any given movement." It is for this reason that field as an analytic tool is highly useful. A field, approach, moreover is ideally suited for understanding how the environment is advocated across different political scales and mediated through multiple claims of justice. This is 
because, as Crossley (2002) recognizes, the power of a field approach comes with its ability to deal with fuzziness across boundaries and concepts, yet the assuredness of understanding practices within those spaces. With respect to ENGO advocacy, mapping the field in which justice claims are deployed helps identify the space within which claims are made, and potentially mediated, and thus allow for an understanding of how conflicting theories and research findings are in fact compatible. In this sense the field of environmental advocacy is not bound by a given context, nor different perceptions of justice. Boudieusian-like fields are in effect methodologically non-parameterized. As Haluza-DeLay (2008) argues, they are not deterministic and thus are highly useful for examining claims around environmental harms.

The power of the field approach is also seen in its ability to map social or other dimensions of space. Its analytic focus is relational and concentrated on positions within a field. That is, rather than assuming that a frame is tied to a specific social actor, this approach looks for patterns of proximity of practices, or claims, in relation to actors and contexts. In many respects, the field approach is an examination of the social gravity of actors in relation to actions and outcomes (Martin 2003). With respect to understanding claim-making and the politics of discourse it is an approach that looks to unearth patterns of relationships, and points of mediation, rather than fixed forms of advocacy.

On this front, social movement scholars have begun to consider how the field analogy can be used to understand strategic action. Filgstein and McAdam $(2011 ; 2012)$ outline a general theory of how fields can be deployed to understand social movements. They note that a field approach is useful for understanding the connection between individual and collective actions and that it is suited to understanding meso-level orders. Because of this, as noted above, a field approach allows for analysis of individuals within organizations, within movements, that are within polities as well as looking at issues nested across dimensions of justice. They argue that strategic action fields are like "Russian dolls" (Filgstein and McAdam 2012: 59) and are thus useful tools for examining multi-scaled and multi-dimensional problems. Filgstein and McAdams, however, focus on the actions of individuals, their practices, and social change rather than the everyday construction of fields and the problem of mapping advocacy space.

The use of field and Bourdieusian analysis is also championed by Rohlinger (2007), who uses field theory to understand the tensions between the homogeneity and heterogeneity of social movement discourses across a range of media venues. Her usage of field is more in line with a study of environmental advocacy claims, the spaces they create, and 
the dimensions of justice they potentially draw upon. Rohlinger's use of field is narrower than Fligstein and McAdam's, but it is also more focused on the discursive spaces and mapping claim-making. She argues that an analysis of discursive fields ${ }^{2}$ can be used to understand "packages," or ideas that are related to a frame, which are used to advance claims by movements (Rohlinger 2007: 129; 2002). Her use of a field approach does not impose frames of one conception of advocacy versus another and instead looks at the range of space where discourse occurs. Rohlinger's approach is suited to analysing conflicting discursive patterns and mediation, which occur in multi-scaled politics and multi-dimensioned advocacy. It is also an approach that returns to earlier conceptions of political arenas (see Hilgartner and Bosk 1988; Gamson 2007) where issues are contested. Essentially, a field-based approach to understanding justice advocacy and claims-making is one that focuses on space of discourse rather than campaigns or specific conceptualizations of issues. It thus does not impose a researcher's understanding on discourse, it is not parameterized, and instead maps what is done in practice which in turn can be used to unearth what might structure future advocacy or justice claims.

The primary goal of this paper is to see how an analysis of field can be used to understand ENGO advocacy claims. This will be done by looking at how Greenpeace and the Sierra Club make their environmental claims and investigating the deployment of different dimensions of justice in these organizations' press releases. If environmental harms are a meta-level injustice, the deployment of justice claims should transcend national and organizational discourse and the field of environmental advocacy will not be shaped in any discernable pattern or mediated through other dimensions of justice. If the environmental harms are multi-scaled and multi-dimensional, but not meta-level injustices, discursive patterns should emerge around specific political contexts, organizations, and other dimensions of justice. If the findings include a mix of both unpatterned meta-level claims and specific patterns of mediating justice claims, then there will be discursive space that is unaffected by political contexts, organizations and other dimensions of justice but at the same

2. The notion of discursive fields can loosely be traced back to Steinberg (1999) who introduced a notion through a number of his works (Snow 2004). Although his work is not Bourdieusian, he argues that "fields contain the genres that can be seen as contextually related when groups construct diagnoses, prognoses, and calls to action, and are partly structured in ongoing processes of hegemony" (Steinberg 1999: 748). This is an understanding shared by media scholars (Benson 1998; Couldry 2003) who apply field to understanding symbolic-power. Steinberg, adds that discursive fields are not fixed or clear-cut -a sentiment expressed by almost all who use a field approach. 
time other discursive space that is patterned around specific organizations and types of justice claims. If there is mix of un-patterned and patterned discursive space, the field approach can identify the spaces that are uniquely those of environmental justice and whether it is mediated by other dimensions of justice.

\section{Methods}

To understand the field of ENGO advocacy, in this paper I examine the press releases of Greenpeace and Sierra Club Canada and their parent organizations. These organizations are by no means representative of all ENGOs, however, they are two of the most established and prominent environmental organizations in Canada and the world. Greenpeace can trace its origins to Vancouver in 1971, when activists using direct action gained unprecedented media attention for their advocacy (Dale 1996). Since then, the organization has grown into an international brand with over three million members and hundreds of millions of dollars in revenue (Vidal 2011). It has presence in 40 countries in all regions of the world and is divided between country-specific organizations and the international organization based in Europe. Sierra Club is by contrast a much older organization, tracing its origins to 1892 in San Francisco. It has hundreds of thousands of members in Canada and the United states and is organized in state and regional chapters. It is less global than Greenpeace, but is international. It has also traditionally distanced itself from direct action, instead promoting education, advocacy, and outreach. Although there are many other ENGOs, the organizations analyzed in this paper are leaders of the environmental movement with respect to media attention and brand recognition. They also represent a range of ENGO advocacy. For these reasons and feasibility, they are the focus of analysis in this paper.

The decision to look at their press releases follows analysis by others looking at naming and shaming (see Ramos, Ron and Thoms 2007; Ron, Ramos and Rodgers 2006) and differs from the more commonly used mention of organizations or frames in news media. It is an approach that allows for an analysis of how advocacy groups want to present themselves, rather than how their messages are received or mediated by journalists. Such a focus allows for an examination of claims-making practices that create a field of environmental advocacy. This is important given that previous research has shown that the reception of social movement messages, especially by media, is often distorted and skewed (Gitlin 1980; Gamson and Wolfsfeld 1993; Ryan 1991; Ryan, Carragee 
and Meinhofer 2001). The focus on press releases also avoids the selection biases of different news outlets (see Oliver and Myers 1999; Early, Martin, McCarthy and Soule 2004 or Andrews and Caren 2010 for analysis of biases). It is thus an approach that is non-parameterized, unfiltered, and directly reflects the discourse of ENGOs.

ENGO press releases were harvested from the Canadian and international parent organization web sites first in February and March of 2009 and again in March 2011. Each press release was captured and printed as a pdf screen shot of what was displayed on organization's web sites. Press releases were then coded by two research assistants for number of characteristics. Inter-coder consistency was obtained through regular coding meetings and repeated coding tests. A minimum of 80 percent exact coding was met before beginning to code the documents and that level was maintained throughout the coding process ${ }^{3}$. A total of 2,236 press releases were coded for the 2006-2010 period. For the purpose of this paper 11 of characteristics are examined, representing Fraser's (2010) three dimensions of justice (redistribution, recognition, and representation) as well an additional dimension of contentious action.

Redistribution was captured by three criteria, including whether or not education (both an organization's outreach or critique of existing pedagogy), economic issues, and/or legal issues were mentioned in an ENGO's press release. Recognition, the most direct measure of environmental claims, was measured through the mention of animals, a habitat (such as ecosystems), health issues (physical and mental or diseases and illnesses), scientific evidence, and/or the internet or e-technology. Representation is captured by the mention of government policies (at the local, provincial, national, international and supra-national levels) and political debates or proceedings. In addition to these dimensions, collective actions (letter/email campaigns, petitions, calls for action/ change, boycotts, legal actions or threat of them, demonstration, and other actions) are treated as a dimension on their own. Although Fraser may have included these as a form of representation, they are treated separately here because of their extra-institutional nature. As a whole, each type of mention represents a continuum of environmental advocacy spanning from specific elements of environmental issues (animals and habitat), to economic justice claims, to appeals to mainstream politics, to contentious politics.

The data are analysed with tabular analysis and then correspondence analysis, which is the same type of analysis used by Bourdieu (1984). He used correspondence analysis because of his emphasis on the notion

3. For additional details on coding, including a dictionary of codes please contact the author. 
that fields are relational (Fligstein 2010: 187) and because the technique is non-parametric and allows for the mapping of practices. Michael Greenacre (2010: 613) notes that, "Correspondence analysis (CA) is a method of data visualization that is applicable to cross-tabular data such as counts, compositions, or any ratio-scale data where relative values are of interest." It is similar to principal components analysis, but is designed for categorical and ratio-scale data. Correspondence analysis essentially maps counts from cross tabulations in multidimensional space. Unlike network analysis, used by many researchers who study social movements to increasingly understand discursive successes of framing mobilization (e.g. Malinick, Tindall, and Diani 2013; Stoddart 2012), the graphical presentation of data does not focus on ties between variables and instead concentrates on positions of coordinates. It plots categories within variables against one another allowing for the analysis of how different dimensions overlap and relate to one another. These features have led Emirbayer and Johnson (2008: 33) to note that the technique helps one to intuitively grasp relationships visually and maps patterns across measures and social actors. The focus of my analysis, with respect to claim-making and dimensions of justice, is to see how claims plot in relation to political contexts, social actors, and competing conceptions of justice. That is, the aim is to identify whether there are patterns of clustering of justice claims. Correspondence analysis is thus meaningful in showing how multidimensional space is shaped, what latent relations potentially exist, and how environmental harms are advocated by ENGOs and potentially mediated through other dimensions of justice.

In the analysis that follows correspondence analysis is used to map the underlying patterns of ENGO advocacy by plotting the 11 characteristics mentioned in press releases across four dimensions of justice. The correspondence analysis presented below was produced in $\mathrm{R}$, using the CA package. The "rowgreen" option, which plots rows in principal coordinates and columns in standard coordinates (Nenadić and Greenacre 2007), was selected to optimize the presentation of information in two dimensions. Other plotting, including 3-D, as well as syntax used to generate plots is available from the author upon request.

As noted above, the primary goal of the analysis is to map the field of advocacy of ENGO press releases. If the environment is a meta-level justice then the deployment of claims should not be shaped in any discernable pattern. If the environment is multi-scaled and mediated by other dimensions of justice, but not a meta-level injustice, patterns should emerge around specific political contexts, organizations, and dimensions of justice. If it is a mix of both, then there will be discursive space that is unaffected but also other space where clustering occurs. 


\section{Analysis}

In order to understand the field of ENGO advocacy, Table 1 begins by reporting the proportion of press releases that mention specific issues or policies by organization. In total Greenpeace Canada (GPC) issued 405 press releases during the 2006-2010 period. Greenpeace International (GPI) issued 659, Sierra Club Canada (SCC) 382, and the US Sierra Club (SCI) issued 790 press releases. The differences in the number of press releases illustrate some key differences. National organizations with smaller budgets and staff issue fewer press releases and SCI uses this mode of communication more than other organizations.

\begin{tabular}{|c|c|c|c|c|}
\hline & GPC & GPI & $\mathrm{SCC}$ & SCI \\
\hline \multicolumn{5}{|l|}{ Redistribution } \\
\hline Education & $2.2 \%$ & $1.7 \%$ & $4.2 \%$ & $8.2 \%$ \\
\hline Economic issues & $87.4 \%$ & $83.6 \%$ & $78.0 \%$ & $85.3 \%$ \\
\hline Legal issues & $50.1 \%$ & $52.2 \%$ & $57.6 \%$ & $61.3 \%$ \\
\hline \multicolumn{5}{|l|}{ Recognition } \\
\hline Animals & $39.0 \%$ & $39.2 \%$ & $30.6 \%$ & $18.6 \%$ \\
\hline Habitat & $89.9 \%$ & $85.6 \%$ & $90.3 \%$ & $88.7 \%$ \\
\hline Health & $16.5 \%$ & $15.6 \%$ & $21.7 \%$ & $34.3 \%$ \\
\hline Scientific evidence & $33.8 \%$ & $37.6 \%$ & $25.7 \%$ & $25.9 \%$ \\
\hline Internet or e-tech & $58.8 \%$ & $70.4 \%$ & $35.3 \%$ & $49.5 \%$ \\
\hline \multicolumn{5}{|l|}{ Representation } \\
\hline Local government policies & $0.5 \%$ & $0.2 \%$ & $3.1 \%$ & $1.4 \%$ \\
\hline Provincial government policies & $23.7 \%$ & $0.6 \%$ & $20.4 \%$ & $4.6 \%$ \\
\hline Federal government policies & $22.2 \%$ & $18.8 \%$ & $55.5 \%$ & $78.5 \%$ \\
\hline International government policies & $10.6 \%$ & $21.2 \%$ & $3.7 \%$ & $0.5 \%$ \\
\hline Supra government policies & $19.5 \%$ & $41.0 \%$ & $11.3 \%$ & $1.0 \%$ \\
\hline Political debate or proceedings & $29.4 \%$ & $41.7 \%$ & $29.6 \%$ & $35.1 \%$ \\
\hline \multicolumn{5}{|l|}{ Actions } \\
\hline Letter/email campaign & $0.0 \%$ & $0.0 \%$ & $0.0 \%$ & $0.1 \%$ \\
\hline Petition & $0.7 \%$ & $0.5 \%$ & $0.8 \%$ & $0.5 \%$ \\
\hline Call for action/change & $44.7 \%$ & $37.6 \%$ & $64.1 \%$ & $52.7 \%$ \\
\hline Boycott & $0.5 \%$ & $0.0 \%$ & $0.0 \%$ & $0.1 \%$ \\
\hline Legal action or threat & $1.5 \%$ & $2.3 \%$ & $4.7 \%$ & $8.6 \%$ \\
\hline Demonstration & $28.4 \%$ & $18.8 \%$ & $4.5 \%$ & $1.9 \%$ \\
\hline Other action & $19.0 \%$ & $37.0 \%$ & $10.2 \%$ & $23.9 \%$ \\
\hline $\mathrm{n}=$ & 405 & 659 & 382 & 790 \\
\hline
\end{tabular}

Analysis of Table 1 also shows differences between organizations and between national and international scales. For example, with respect to policies, national organizations have more press releases mentioning provincial policies whereas the parent organizations tend to focus more on national policies, and in the case of GPI -international and supra- 
national policies. This shows that ENGOs operate differently across multi-scaled political contexts. The table likewise shows the organizations share similarities in their use of economic and legal claims, claims for redistributive justice, but differ on education. They also share similarities in a focus on habitat but differ on the focus on animals and other direct attempts to recognize environmental injustices. The organizations show little similarity in their claims around representation and contentious actions. As a result, Table 1, like the environmental and social movement literature, shows mixed findings that offer both evidence of meta-level injustice crossing political contexts and acting independently of other dimensions of justice, while also showing that there are unique spaces of difference.

Although Table 1 is informative, it does not offer clear-cut patterns of the field of ENGO advocacy. To explore this further, Figure 1 plots the underling information of Table 1, using correspondence analysis, based on the counts of mentions of each factor in multidimensional space. To offer a cleaner plotting of mentions of different justice claims, the "not mentioned" categories are supressed in the presentation. This only marginally affects the plotting of claims and offers a better portrait of the field of ENGO advocacy. (For details on the differences in plotting with and without suppression and additional statistical information please contact the author.)

If we begin by first examining the Y-axis of Figure 1, we can see a number of characteristics are associated with Canadian organizations versus their parent organizations. GPC and SCC are both found in the two upper quadrants of the figure. (It should be noted that the values on the legend are used to help identify space on the two-dimensional plot, but do not correspond directly to the distances calculated in the plotting of claims in the correspondence analysis. These values are merely a visual tool. The image is also stretched to make labels more legible. At the same time abbreviated labels correspond to the 11 characteristics shown in Table 1). The organizations are marked with triangles and their acronyms. If one examines the top half of the figure, she will see that the claims plotted closest to these organizations include mentions of local and provincial issues and policies, petitions, boycotts, and demonstrations. The parent organizations are seen in the bottom two quadrants of the figure and the organizations are also marked with triangles and their acronyms. Here we see legal and other actions, education, political debates, and federal, international and supra-national policies forming that space. The parent organizations are associated with more international and transnational actions as well as different actions. Looking at the field of ENGO press advocacy in this manner does not offer evidence to sup- 
port claims of the environment as a pure meta-level injustice that transcends political contexts.

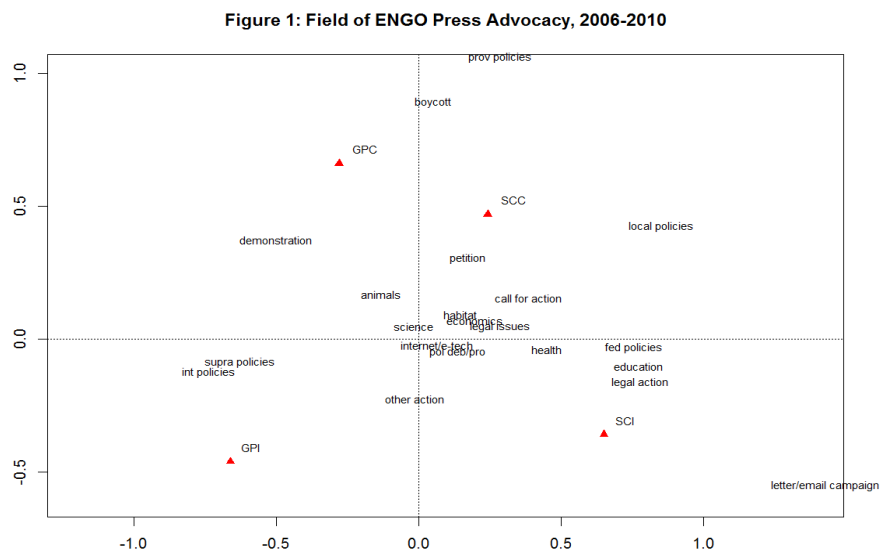

If we focus on the X-axis, we see that the GPC and GPI are located on the on two left-side quadrants of Figure 1 and SCC and SCI are located on the two right-side quadrants. When this is done we see a number of differences that are consistent with each organization, irrespective of national or international contexts. Greenpeace's press advocacy is aligned with more radical actions and is also defined by a wider range of politics. Sierra Club's advocacy is defined by legal actions, education, and federal, provincial and local politics. For those familiar with the history of both organizations, this would come as no surprise. Greenpeace has a long history of direct action, whereas Sierra Club has worked in more institutional contexts. When the ENGO field of advocacy is examined in this way we again do not find evidence of pure meta-level injustice claims, but rather ones that are specific to each organization.

Interestingly, the differences found in looking across the $\mathrm{Y}$ and $\mathrm{X}$ axes are largely those associated with justice claims linked to representation and action and to a lesser extent redistribution. If one examines the centre of Figure 1, which is the space that is least influenced by political scale or specific organizations, we begin to see what might uniquely define environmental advocacy space. In the centre region of Figure 1, we see that most claims are around recognition or aspects that are directly tied to the environment as well as mention of economic and legal issues and calls for action. Closest to the centre is science and habitat. As one pans out from the centre we see environmental issues that are more aligned with specific organizations and the further one goes from the mid-point we see the patterns described above. Figure 1 offers evi- 
dence of both meta-level characteristics, as well as mediation between environmental (recognition) justice claims and those around redistribution. At the same time the figure identifies the space that is most tied to political scale, or contexts, as well as organizations. What does all of this mean with respect to the conflicting claims in the transnational social movement and justice literatures versus applied studies looking at environmental media advocacy?

The data presented are in line with Tarrow's (2005) theorization of rooted cosmopolitans and transnational activists. The former are people who act in local and national contexts while espousing global views and the latter are those who reach out to international venues to advocate for local issues. Tarrow's insights on the relationships of individuals to issues and spheres of activism are well-suited for parsing out the multiscaled political activism and advocacy in an increasingly transnational world. The data presented also reflect observations by Fligstein and McAdam $(2011$; 2012) who contend that politics occur in nested fields both in terms of political and organizational scales. Last, the findings point to productive ways of understanding how meta-level injustices relate to other dimensions of claims-making. They show how environmental harms advocated by ENGOs are mediated through non-environmental justice claims and also show the discursive space that is uniquely environmental.

It is worth cautioning, however, that the field approach taken in the paper is only the first step in understanding how ENGOs advocate across contexts and issues. To borrow Crossley's phraseology (2002; 2003), I have offered a Bourdieusian-inspired approach to fields rather than one that fully applies his model. A number of Bourdieu's key theoretical components that operate within fields have not been analysed in this paper. A fuller application of his theory would compare the spaces identified in this paper with more environmental organizations and other social movements to see how they align with the space identified above. They would also look at how practices shape habitus, or to use the concepts from Rohlinger's (2007) model -how these spaces reflect packages that are directly tied to advocacy frames and campaigns. Fligstein and McAdam $(2011 ; 2012)$ argue that this can be done by looking at the "social skill" of actors to navigate the ongoing construction of fields. This paper, then, offers a preliminary base to work from, a map of ENGO activism, and a proof-of-concept to how Boudieusian field approaches and correspondence analysis can be applied in social movement, media, and environmental advocacy research. The field approach, moreover, offers a potential methodology for analysing processes of mediation, and specif- 
ically how environmental harms are advocated across multiple political scales and dimensions of social justice.

\section{Conclusion}

After examining the environmental press advocacy of Greenpeace and Sierra Club Canada and their parent organizations, it becomes apparent that the field of ENGO advocacy is defined by at least three spaces. One that is national, one that is organizational, and a third that is environmental. In each space environmental advocacy was mediated by other dimensions of justice. By examining whether or not different environmental and justice claims are mentioned by organizations rather than trying to code their campaigns or frames, we gain a better understanding of how conflicting conclusions are found among the transnational advocacy, environmental justice, and social movement literatures.

Those identifying transnational advocacy and meta-level injustices have focused on networks of like-minded NGOs and have largely assumed that they share normative understandings of the issues for which they advocate. The analysis presented in this paper shows that the relationships among ENGOs in different contexts are more complex. By looking at spaces associated with political scale as well as specific organizations we gain an understanding of which claims are likely to transcend the local and national context as well as which ones are most associated with different ENGOS. Analysis of national space showed that it is defined by level of political issues, debates, and contentious actions. The mediating dimensions of this space are representation and actions. Plotting the contours of national helps account for which issues, and packages that frame them, remain domestic and which ones potentially enter the transnational sphere. With respect to organizational space, we see that Greenpeace mentioned more radical actions and international policies and Sierra Club more institutional and policy-based issues like legal and educational issues. Like national space, differences in organizational space are shaped by dimensions of representation and actions. The claims-making that was not clustered around specific political contexts or organizations is likely the discursive field unique to environmental advocacy -the metal-level frame that Fraser (2010) theorizes. Environmental advocacy space was defined by the elements that were most common across organizations' claims-making and most linked to recognition of potential environmental harms. Habitat, science, legal and economic issues all feature prominently in the environmental advocacy space - it is the space where environmental issues are debated and the 
space that operates in both transnational and domestic contexts. It is also, however, a space mediated by redistributive (or economic) dimensions of justice.

Using a Bourdieusian field approach has allowed for a non-parametric mapping of how organizations present their advocacy. Unlike a framing approach, commonly used by social movement researchers, which focuses on the campaigns of given organizations or their reception filtered through the media, a field approach illustrates the space in which those frames are developed. Identifying the three spaces of ENGO press advocacy allows researchers to understand how advocacy works across contradictory contexts. Advocacy by an organization differs from advocacy in different political arenas and this likely differs by issue. Identifying these spaces and the overall field in which they operate focuses on the contours of how ENGOs adopt frames and shifts the analytic focus from predetermined relations to unrestrained portraits of what organizations do. It examines how ENGOs practice their advocacy rather than how researchers assume they do their activism.

Such an analytic focus thus allows for understanding complex and contradictory conclusions. As a result, this paper shows evidence of transnational conduits, but at the same time, demonstrates that specific contexts are still relevant. This finding is supported by Tarrow (2005) who recognizes the continued importance of nation-states and who theorizes how activists relate to multi-scaled political contexts. A field approach shows that the practice of advocacy is not an either/or situation, one that is either transnational or local, but rather one that is situational and relational with respect to space of political engagement. The approach also shows that the process of ENGOs claims-making against environmental harms is one that is mediated by other dimensions of justice.

\section{REFERENCES}

Andrews, Kenneth T. and Neal Caren. 2010. "Making the News: Movement Organizations, Media Attention, and the Public Agenda." American Sociological Review 75: 841-66.

Benson, Rodney. 1998. "Field Theory in Comparative Context: A New Paradigm for Media Studies." Theory and Society 28: 463-498.

Bob, Clifford. 2007. The Marketing of Rebellion: Insurgents, Media, and International Activism. New York: Cambridge University Press.

Bourdieu, Pierre. [1998] 2006. "On Television," Reprinted in Media and Cultural Studies: Key Works edited by Meenakshi Gigi Durham and Douglas M. Kellner. Malden, MA: Blackwell Publishing. 
Bourdieu, Pierre. [1984] 1993. The Field of Cultural Production. New York: Columbia University Press.

Bourdieu, Pierre. [1984b] 2010. Distinction: A Social Critique of the Judgement of Taste. Abingon, UK: President of the Fellow of Harvard College and Routledge.

Bourdieu, Pierre and Loïc J. D. Wacquant. 1992. An Invitation to Reflexive Sociology. Chicago: University of Chicago Press.

Couldry, Nick. 2003. "Media Meta-Capital: Extending the Range of Bourdieu's Field Theory." Theory and Society 32: 653-677.

Crossley, Nick. 2003. "From Reproduction to Transformation: Social Movement Fields and the Radical Habitus." Theory, Culture, and Society 20 (6): 43-68.

Crossley, Nick. 2002. Making Sense of Social Movements. Buckingham: Open University Press.

della Porta, Donatella. 2005. "Globalizations and Democracy." Democratization 12: 668-85.

della Porta Donatella, Massimiliano Andretta, Lorenzo Mosca and Herbert Reiter. 2006. Globalization From Below: Transnational Activists and Protest Networks. Minneapolis, MN: University of Minnesota Press

Dale, Stephen. 1996. McLuhan's Children: The Greenpeace Message and the Media. Toronto, ON: Between The Lines.

Downs, Anthony. 1972. "Up and Down with Ecology: The 'Issue-Attention Cycle' http://www.nationalaffairs.com/public interest/detail/up-anddown-with-ecologythe-issue-attention-cycle (Accessed 14/06/2013).

Earl, Jennifer, Andrew Martin, John D. McCarthy and Sarah A. Soule. 2004. "The Use of Newspaper Data in the Study of Collective Action." Annual Review of Sociology 30: 65-80.

Emirbayer, Mustafa and Victoria Johnson. 2008. "Bourdieu and Organizational Analysis." Theory and Society 37: 1-44.

Fligstein, Niel and Doug McAdam. 2012. A Theory of Fields. New York: Oxford University Press.

Fligstein, Niel and Doug McAdam. 2011. "Toward a General Theory of Strategic Action Fields." Sociological Theory 29 (1):1-26.

Fraser, Nancy. 2010. Scales of Justice: Reimagining Political Space in a Globalizing World. New York Columbia University Press.

Fraser, Nancy. 2008. “Abnormal Justice.” Critical Inquiry 34 (3): 393-422.

Fraser, Nancy 2005. "Reframing Justice in a Globalizing World." New Left Review 1-19. 
Futrell, Robert. 2003. "Framing Processes, Cognitive Liberation, and NIMBY Protest in the U.S. Chemical-Weapons Disposal Conflict." Sociological Inquiry 73 (3):359- 386.

Gamson, William A.. 2007. "Bystander, Public Opinion, and the Media," in the Blackwell Companion to Social Movements, edited by David A Snow, Sarah A Soule, and Hanspeter Kriesi. Malden, MA: Blackwell.

Gamson, William A. and Gadi Wolfsfeld. 1993. "Movements and Media as Interacting Systems." Annals of the American Academy of Political \& Social Science 528 (July): 114-25.

Gitlin, Todd. 1980. The Whole World is Watching. Berkley: University of California Press.

Greenacre, Michael J. 2010. "Correspondence Anlysis." Wiley Interdisciplinary Reviews: Computational Statistics 2 (5): 613-619. DOI: 10.1002/ wics. 114

Haluza DeLay, Randolph. 2008. "A Theory of Practice for Social Movements: Environmentalism and Ecological Habitus," Mobilization 13 (2): 205218.

Hilgartner, Stephen and Charles L. Bosk, 1988.'The Rise and Fall of Social Problems: A Public Arenas Model', American Journal of Sociology 94 (1): 53-78.

Keck, Margaret E. and Kathryn Sikkink. 1998. Activists Beyond Borders: Advocacy Networks in International Politics. Ithaca, NY: Cornell University Press.

Leiserowitz, Anthony. 2007. "International public perception, opinion, and understanding of climate change: Current patterns, trends, and limitations." Thematic paper for: Human Development Report 2007: Climate Change and Human Development? Rising to the Challenge. United Nations Development Program. http://hdr.undp.org/en/reports/global/ hdr2007-2008/papers/leiserowitz_anthony.pdf

Leggett, Jeremy 2001. The Carbon War: Global Warming and the End of the Oil Era. London, UK: Routledge.

Lizardo, Omar. 2012. "The Three Phases of Bourdieu's US Reception: Comment on Lamont." Sociological Forum 27 (1): 238-244.

Malinick, T.E., Tindall, D.B. \& Diani, M.. 2013. "Network centrality and social movement media coverage: A two-mode network analytic approach." Social Networks, 35: 148-158.

Martin, John Levi. 2003. "What is Field Theory?" American Journal of Sociology 109 (1): 1-49.

McAdam, Doug, Robert J. Sampson, Simon Weffer and Heather MacIndoe. 2005. "'There will be Fighting in the Streets:' The Distorting Lens of Social Movement Theory. Mobilization 10: 1-18. 
Meyer, John W., John Boli, George M. Thomas, and Francisco O. Ramirez. 1997. 'World society and the nation state'. American Journal of Sociology 103 (1):144-81.

Montpetit, Eric. 2003. Misplaced Distrust: Policy Networks and the Environment in France, the United States, and Canada. Vancouver, BC: UBC Press.

Morris, Aldon. 1981. "Black Southern Student Sit-in Movement: An Analysis of Internal Organization." American Sociological Review 46: 744-67.

Nenadić, Oleg and Michael Greenacre. 2007. "Correspondence Analysis in R, with Two- and Three-Dimensional Graphics: The ca Package." Journal of Statistical Software 20 (3): 1-13.

Oliver, Pamela E. and Daniel J. Myers. 1999. "How Events Enter the Public Sphere: Conflict, Location, and Sponsorship in Local Newspaper Coverage of Public Events." American Journal of Sociology 105:38 87.

Ramos, Howard; James Ron and Oskar N. T. Thoms. 2007. "Shaping the Northern Media's Human Rights Coverage, 1986-2000." Journal of Peace Research 44 (4): 385-406.

Rohlinger, Dena A.. 2007. "American Media and Deliberative Democratic Processes.” Sociological Theory 25 (2): 122-148.

Rohlinger, Dena A. 2002. "Framing the Abortion Debate: Organizational Resources, Media Strategies, and Movement-Countermovement Dynamics.” Sociological Quarterly 43: 479-507.

Ron, James; Howard Ramos and Kathleen Rodgers. 2006. "What Shapes the West's Human Rights Focus?" Contexts 5 (3): 23-28.

Ryan, Charlotte. 1991. Prime Time Activism: Media Strategies for Grassroots Organizing. Boston, MA: South End Press.

Ryan, Charlotte, Kevin M. Carragee and William Meinhofer. 2001. "Theory into Practice: Framing, the News Media, and Collective Action." Journal of Broadcasting \& Electronic Media 45 (1): 175-82.

Sallaz, Jeffrey J. and Jane Zavisca. 2007. "Bourdieu in American Sociology, 1980-2004." Annual Review of Sociology 33: 21-41.

Skalir, Leslie. 2002. Globalization. New York: Oxford University Press.

Smith, Jackie. 1998. "Global Civil Society? Transnational Social Movement Organizations and Social Capital." American Behavioral Scientist 42 (1): 93-107.

Smith, Jackie. 2007. "Transnational Processes and Social Movements." The Blackwell Companion to Social Movements, David A. Snow, Sarah H. Soule and Hanspeter Kriesi [eds]. Malden, MA: Blackwell.

Snow, David A. 2004. "Framing Processes, Ideology, and Discursive Fields." The Blackwell Companion to Social Movements, David A. Snow, Sarah H. Soule and Hanspeter Kriesi [eds]. Malden, MA: Blackwell. 
Steinberg, Marc W. 1999. "The Talk and Back Talk of Collective Action: A Dialogic Analysis of Repertoires of Discourse Among Nineteenth-Century English Cotton Spinners." American Journal of Sociology 105:736-80.

Steinmetz, George. 2008. "The Colonial State as a Social Field: Ethnographic Capital and Narrative Policy in the German Overseas Empire before 1914." American Sociological Review 73: 589-612.

Stoddart, Mark C. J.. 2012. Making Meaning Out of Mountains: The Political Ecology of Skiing. Vancouver: UBC Press.

Stoddart, Mark C. J. and Howard Ramos. 2013. "Going Local: Calls for Local Democracy and Environmental Governance at Jumbo Pass and the Tobeatic Wilderness Area." Interface 5 (1): 229-252.

Taylor, Dorceta E.. 2000. “The Rise of the Environmental Justice Paradigm: Injustice Framing and the Social Construction of Environmental Discourses." American Behavioral Scientist 2000 43: 508-580.

Tarrow, Sidney. 2005. The New Transnational Activism. New York, NY: Cambridge University Press.

Vidal, John. 2011. "Greenpeace at 40: A Global Brand in Good Health or an Out-Of-Touch Bureaucracy?" Guardian http://www.guardian.co.uk/ environment/2011/sep/15/greenpeace-40-year-anniversary (Accessed 15/06/2013).

Wood, Lesley J.. 2012. Direct Action, Deliberation, and Diffusion. Cambridge University Press: New York.

Howard Ramos is Professor in the Department of Sociology and Social Anthropology at Dalhousie University. His research focuses on social movements, environment, and social justice. He is author, with Kathleen Rodgers, of Protest and Politics: The Promise of Social Movement Societies (2015), and, with Suzanne Staggenborg, Social Movements 3rd edition (2015).

Howard.Ramos@,Dal.Ca 
376 C) Canadian Journal of Sociology/Cahiers Canadiens de Sociologie 40(3) 2015 